\title{
SITE-SPECIFIC SEDIMENT QUALITY VALUES FOR THE GULF OF CÁDIZ (SPAIN) AND SAN FRANCISCO BAY (USA), USING THE SEDIMENT QUALITY TRIAD AND MULTIVARIATE ANALYSIS
}

\author{
VALORES DE CALIDAD DE SEDIMENTO ESPECÍFICOS PARA EL \\ GOLFO DE CÁDIZ (ESPAÑA) Y LA BAHÍA DE SAN FRANCISCO (EUA), \\ USANDO EL MÉTODO "TRIAD" Y EL ANÁLISIS MULTIVARIANTE
}

\author{
T.A. DelValls \\ P.M. Chapman ${ }^{2}$ \\ ' Departamento de Química Física, Facultad de Ciencias del Mar \\ Universidad de Cádiz \\ Apartado 40 \\ 11510 Puerto Real, Cádiz, España \\ E-mail: angel.valls@uca.es \\ ${ }^{2}$ EVS Environment Consultants \\ 195 Pemberton Avenue \\ North Vancouver, British Columbia V7P 2R4, Canada
}

Recibido en septiembre de 1997; aceptado en marzo de 1998

\begin{abstract}
Sediment quality values need to be developed to help protect public health and the environment. Data derived from sediment chemistry, sediment toxicity tests and macrobenthic infaunal community structure from two separate integrative studies (sediment quality triad) conducted in the Gulf of Cádiz and in San Francisco Bay were analyzed by multivariate statistical techniques (principal component analysis [PCA] and factor analysis) to identify the concentration ranges of the chemicals associated with adverse effects. Application of PCA-factor analysis to the data matrix for the Gulf of Cádiz showed that the three data types could be represented by five principal factors, whereas for San Francisco Bay, there were four principal factors. These factors, as well as chemical concentrations and biological effects, were used to establish site-specific sediment quality values for each area studied. Positive prevalence of these factors in the cases studied (seven stations in the Gulf of Cádiz and nine in San Francisco Bay) was used to establish the ranges of chemical concentrations associated with adverse effects. The values proposed for the Gulf of Cádiz, in terms of concentrations at or below which biological effects have been shown to be minimal, are (in $\mathrm{mg} \mathrm{kg}^{-1}$ of dry sediment): chromium, 101.2; lead, 66.8; linear alkylbenzenesulphonate, 12.8; silver, 1.2; and mercury, 0.46 . The values proposed for San Francisco Bay are (in $\mathrm{mg} \mathrm{kg}^{-1}$ of dry sediment): zinc, 156; chromium, 110; nickel, 88; copper, 68; arsenic, 58; lead, 49; tin, 8.0; silver, 4.0; mercury, 0.37; PCBs, 0.057; and DDTs, 0.00224 .
\end{abstract}

Key words: sediment quality values, integrative assessment, sediment quality triad, multivariate analysis (PCA-factor), ecotoxicology, marine pollution.

\section{RESUMEN}

La protección de la salud pública así como la medioambiental plantea la necesidad de establecer valores de calidad de sedimento. Se ha utilizado la base de datos, resultado de un estudio integrado 
(sediment quality triad), de concentraciones de contaminantes, resultados de ensayos de toxicidad y estructura de la comunidad macrobentónica disponible en sedimentos del Golfo de Cádiz y en la Bahía de San Francisco, de manera conjunta y mediante el uso de técnicas estadísticas multivariantes (análisis de componentes principales y análisis de factores), con el objetivo de establecer las concentraciones de sustancias xenobióticas que están asociadas con el efecto biológico. La aplicación del análisis multivariante sobre la matriz de datos obtenidos en el Golfo de Cádiz muestra que las variables correspondientes a los tres tipos de datos utilizados pueden agruparse en cinco factores principales, mientras que en la Bahía de San Francisco, pudieron agruparse en cuatro factores. El valor positivo de aquellos componentes que incluyen concentraciones de contaminantes, junto con el efecto biológico en los distintos casos estudiados (siete estaciones seleccionadas en el Golfo de Cádiz y nueve en la Bahía de San Francisco), ha sido utilizado para establecer los intervalos de las concentraciones de contaminantes que se encuentran asociadas con daños biológicos. Los valores para el Golfo de Cádiz, en términos de las concentraciones a las cuales no se produce el efecto biológico o éste es mínimo, son (en $\mathrm{mg} \mathrm{kg}^{-1}$ de peso seco de sedimento): cromo, 101.2; plomo, 66.8; alquilbencenosulfonato lineal, 12.8; plata, 1.2; y mercurio, 0.46. Los criterios para la Bahía de San Francisco son (en $\mathrm{mg} \mathrm{kg}^{-1}$ de peso seco de sedimento): zinc, 156; cromo, 110; níquel, 88; cobre, 68; arsénico, 58; plomo, 49; estaño, 8.0; plata, 4.0; mercurio, 0.37; PCBs, 0.057; y DDTs: 0.00224.

Palabras clave: criterios de calidad de sedimentos, métodos integrados, análisis multivariante (PCA-factor), ecotoxicología, polución marina.

\section{INTRODUCTION}

There is a need to develop criteria that can be used to assess sediment quality. As Chapman (1991) pointed out, the term sediment quality criteria is inappropriate with respect to environmental quality, since it is a narrowly and rigidly defined performance standard. For this reason we use the term sediment quality values, defined as broad performance standards that are applied on the basis of best professional judgement, because it describes a level with some flexibility, in recognition of environmental realities that are not reflected in the term criteria.

Sediment quality values (SQV) are a controversial subject. This controversy covers a range of questions, from whether such values are necessary to whether they can be developed, and to what the best means of developing them is. The present investigation combines sediment chemistry and sediment toxicity test measures, with in situ studies (the sediment quality triad [SQT]) of samples taken synoptically, and presents a first attempt to use these SQT data to derive quantitative values for the chemical contaminants measured (fig. 1). Data sets were obtained from two different integrative studies carried out in littoral ecosystems in the Gulf of Cádiz (Bay of Cádiz, fig. 2; and salt-marsh of

\section{INTRODUCCIÓN}

Existe la necesidad de desarrollar guías que puedan ser utilizadas para determinar la calidad de los sedimentos. Según Chapman (1991), el término criterios de calidad de sedimento es una palabra inapropiada para utilizarse con respecto a la calidad ambiental, ya que es demasiado rígida para establecer patrones de calidad. Por esta razón, nosotros utilizamos el término valores de calidad de sedimento, definidos como patrones basados en el mejor de los juicios profesionales posibles, ya que de esta forma se describen los niveles con cierta flexibilidad y se reconoce la realidad medioambiental que no está recogida en el término criterios.

Los valores de calidad de sedimento (SQV) son un tema controvertido. Esta controversia cubre un intervalo de preguntas, particndo de si son, o no, necesarios hasta si es posible establecerlos, y cuál es la mejor forma posible de desarrollarlos. La investigación que se describe combina medidas de toxicidad y química de sedimentos, con estudios realizados in situ (sediment quality triad [SQT]) sobre muestras obtenidas de forma sinóptica y presenta un primer intento para usar estos datos del SQT para calcular valores cuantitativos de los contaminantes químicos medidos (fig. 1). Las series de datos se obtuvieron a partir de dos 


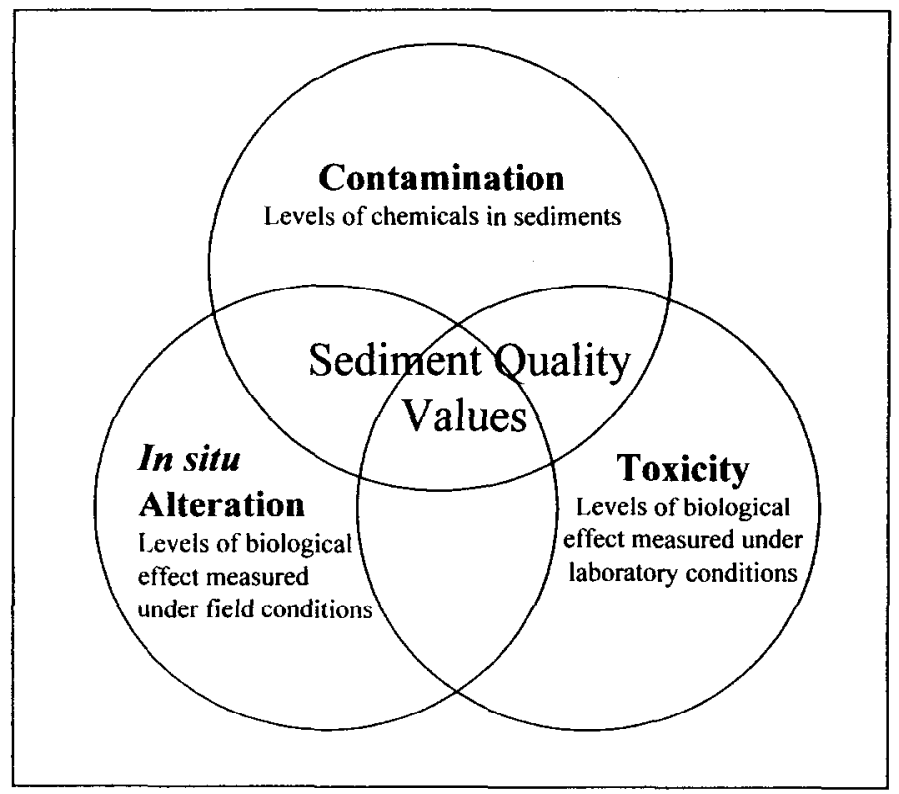

Figure 1. Schematic representation of the sediment quality triad. The potential overlapping area between chemical and biological components is where the site-specific sediment quality values could be calculated by using multivariate analysis.

Figura 1. Representación esquemática del sediment quality triad. El área solapada entre los componentes químicos y biológicos representa la zona potencialmente disponible para calcular los valores específicos de calidad de sedimento para las zonas estudiadas utilizando el análisis multivariante.

the Barbate River, fig. 3) and in San Francisco Bay (fig. 4).

There are several monographs on the uses of principal component analysis (PCA) in the examination of environmental data. However, in spite of extensive literature, the use of PCA in the evaluation of environmental data is increasing rather slowly (Zitko, 1994). A multivariate statistical analysis, based on PCA as the extraction method during the evaluation of data using factor analysis, was proposed to cstablish the ranges of chemical concentration associated with adverse effects. Specific considerations in the application of the PCA to the data included: (a) Toxic chemicals have an influence on measurable biological responses that outweighs the influence of natural physicochemical factors; (b) chemicals quantified for the analysis are those that are known to be responsible for estudios integrados diferentes, llevados a cabo en ecosistemas litorales del Golfo de Cádiz (Bahía de Cádiz, fig. 2; y marismas del río Barbate, fig. 3) y en la Bahia de San Francisco (fig. 4).

Existen varias monografias donde se utiliza el análisis de componentes principales (PCA) para estudiar datos medioambientales. Se podría esperar, por tanto, un aumento de la literatura que hace uso del PCA en la evaluación de datos medioambientales; sin cmbargo, ésta aumenta muy lentamente (Zitko, 1994). En el presente estudio, se propone la evaluación total de los datos por análisis de factores (análisis estadístico multivariante), utilizando el PCA como proceso de extracción, para establecer los intervalos de concentración de contaminantes asociados con efectos adversos. Las consideraciones específicas en la aplicación del PCA a 


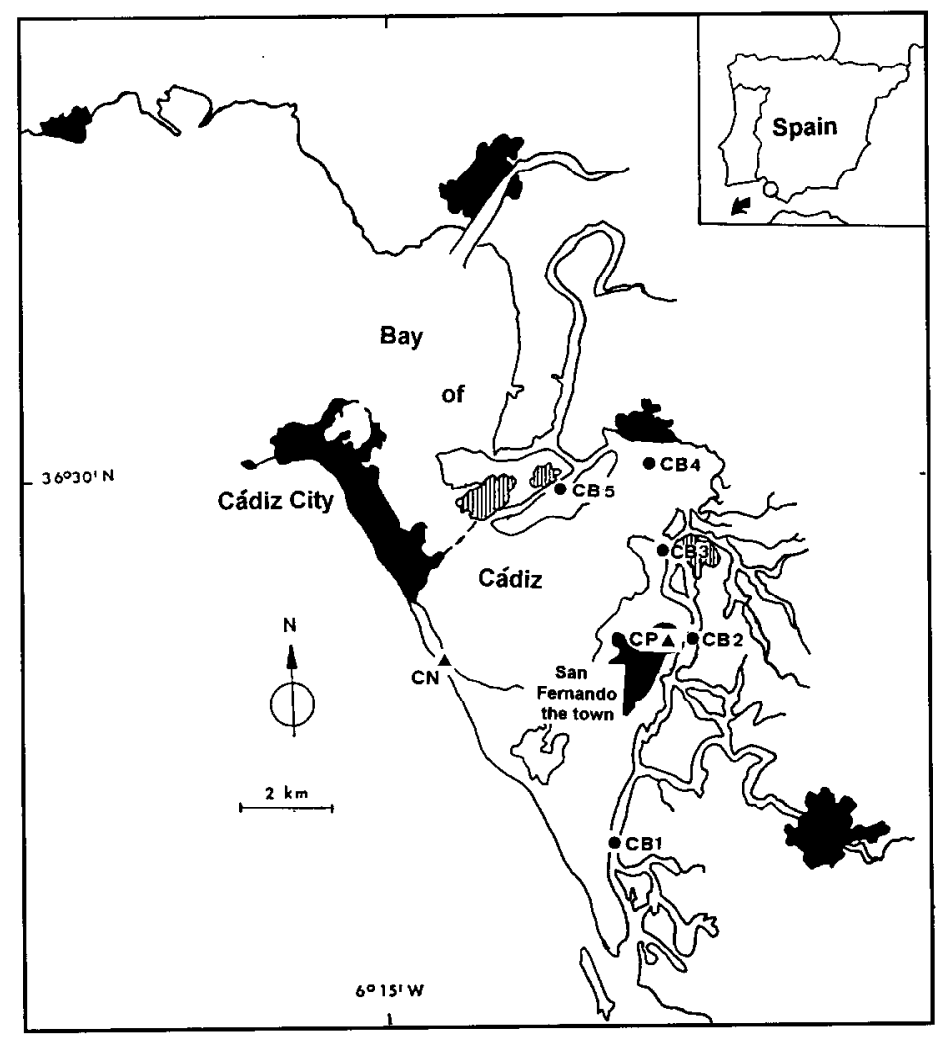

Figure 2. Map of the Bay of Cádiz, showing the general areas sampled and locations of the sampling stations. Negative and positive controls ( $\mathrm{CN}$ and $\mathrm{CP}$, respectively) used in the toxicity tests are represented by triangles $(\boldsymbol{A})$. Urban locations are represented by dark areas and industrial locations by vertical lines.

Figura 2. Mapa de la Bahía de Cádiz, mostrando el área general de muestreo y la localización de las estaciones seleccionadas. Los controles de toxicidad, negativo $(\mathrm{CN})$ y positivo $(\mathrm{CP})$, usados en los tests de toxicidad están representados por triángulos $(\mathbf{\Delta})$. La localización de las zonas urbanas es representada por áreas oscuras y la localización de zonas industriales por áreas con líneas verticales.

the measured effects, although co-varying chemicals not quantified may have an influence on the biological tests; (c) although the chemicals probably act together as mixtures (i.e., synergistically) to influence the biological tests, their patterns in multivariate statistical analysis are estimated singly in the PCA data analyses.

The objectives of this article are: (a) to compare both SQT studies by establishing the ranges of chemical concentration associated los datos incluyen: (a) Las respuestas biológicas se ven más afectadas por las sustancias tóxicas que por los factores fisicoquímicos naturales; (b) los contaminantes químicos cuantificados son aquellos conocidos que son responsables del efecto biológico, aunque los contaminantes que varien conjuntamente y los no cuantificados podrían tener también influencia en los tests biológicos; y (c) aunque los contaminantes actúan probablemente juntos como mezclas (i.e., sinergéticamente) en su influencia en los 


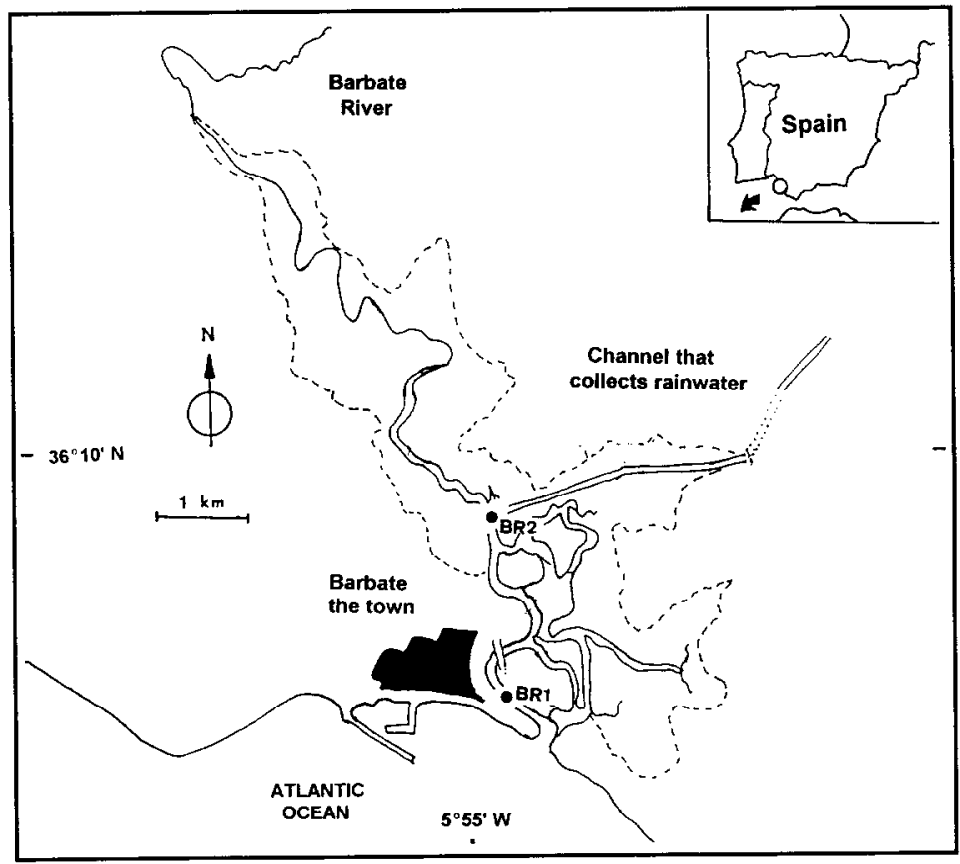

Figure 3. Map of the Barbate River salt-marsh, showing the general areas sampled and locations of the sampling stations.

Figura 3. Mapa de la marisma del río Barbate, mostrando el área general de muestreo y la localización de las estaciones seleccionadas.

with adverse effects (SQV); and (b) to demonstrate that the multivariate analysis described can be used as an exploratory tool to complement the integrative assessment used: the SQT.

\section{MATERIAL AND METHODS}

\section{Approach}

The present study was performed at seven stations in two shallow littoral ccosystems in the Gulf of Cádiz, in southwestern Spain (figs. 2, 3), and nine stations in San Francisco Bay (USA) (fig. 4). Both ecosystems have a low water depth. For this reason, contamination of the water column is largely determined by the processes of chemical transfer across the water-sediment interface. Detailed descriptions of both sites and stations are reported by tests biológicos, sus tendencias en los análisis estadísticos multivariantes son estimadas de manera singular.

Los objetivos de este artículo son: (a) comparar los dos estudios de SQT estableciendo los intervalos de la concentración de contaminantes asociados con efectos adversos (SQV); y (b) demostrar que la técnica multivariante descrita puede ser utilizada como una herramienta exploratoria para complementar el método integrado de valoración: el SQT.

\section{MATERIALES Y MÉTODOS}

\section{Descripción del área}

Este estudio fue desarrollado sobre siete estaciones en dos sistemas litorales del Golfo de Cádiz, en el suroeste de España (figs. 2, 3), y sobre nueve estaciones en la Bahía de San 


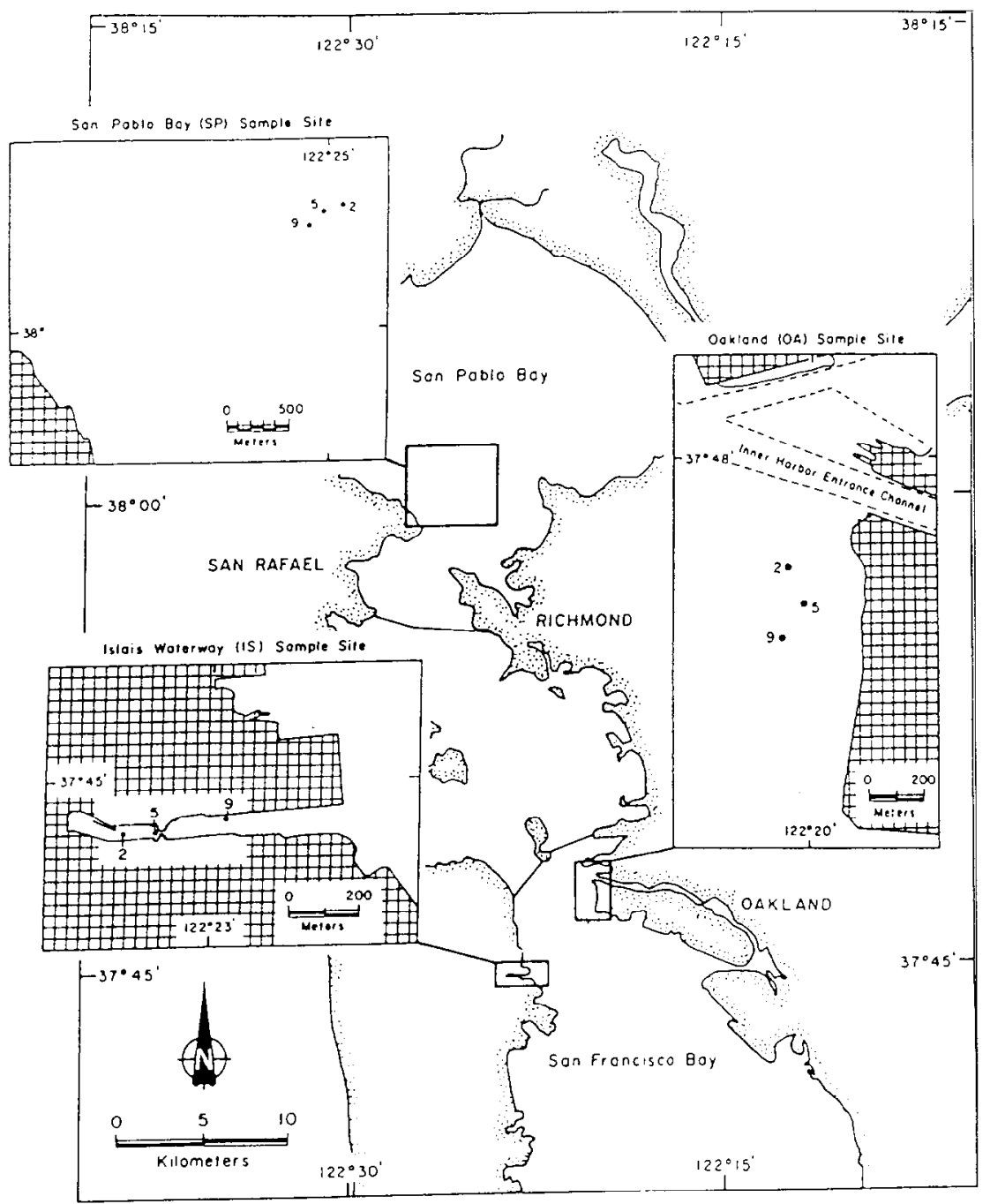

Figure 4. Map of San Francisco Bay, showing the general areas sampled and locations of the sampling stations within the sites sampled (from Chapman et al., 1987).

Figura 4. Mapa de la Bahía de San Francisco, mostrando el área general de muestreo y la localización de las estaciones seleccionadas (adaptada de Chapman et al., 1987).

DelValls et al. (1996, 1997, 1998a, b, c) and Chapman et al. (1987), respectively. "Clcan" sediment $(\mathrm{CN})$ was used in both studies as the. negative control reference (fig. 2), together with samples of oceanic water for toxicity tests. Also, "polluted" sediment (CP) collected from the untreated sewage discharge point located in
Francisco (EUA) (fig. 4). Ambos ecosistemas ticnen profundidades pequeñas. Por esta razón, la contaminación de la columna de agua está altamente determinada por procesos de transferencia de especies quimicas a través de la interfase agua-sedimento. Una descripción detallada de ambos sitios y estaciones se ha 
the town of San Fernando (fig. 2) and its extracted interstitial water were used as a positive control (DelValls et al., 1996) during toxicity testing in the Gulf of Cádiz.

\section{Sediment quality triad components}

The set of variables selected for both studies and for each component are described briefly in figure 5 . The data were analyzed by multivariate statistical analysis (factor analysis using the PCA extraction procedure), a multivariate statistical technique, to explore variable distributions (for the Gulf of Cádiz, chemical concentrations $n=17$ and biological effects $n=$ 10; for San Francisco Bay, chemical concentrations $n=18$ and biological effects $n=12$ ). This approach involved the investigation of potential multidimensional relationships between the values for chemical data and biological effects, and was followed by the classification of the samples into groups, where groups could be identified. PCA applied to factor analysis is a technique used to reduce the dimensionality of the original set of variables in a different manner. The objective of PCA-factor is to derive a reduced number of new factors as linear combinations of the original variables, which will provide a description of the structure of the data with a minimum loss of information. The factor analysis was performed on the correlation matrix, i.e., the variables were autoscaled (standardized) so as to be treated with equal importance. All analyses were performed using the PCA option of the FACTOR procedure, followed by the basic setup for factor analysis procedure (P4M) from the BMDP statistical software package (Frane et al., 1985). Information on matrix type, chemical concentrations, endpoints from sediment toxicity tests, parameters of macrobenthic infaunal community structure and sampling stations was used to interpret patterns in the data set.

The data base contained information from a total of seven sediment samples collected in the Gulf of Cádiz. Sediment chemical data covered the concentrations of 14 heavy metals, linear alkylbenzenesulphonate (LAS), organic carbon (TOC), and the specific surface $(\sigma)$. Biological effect data were provided by six sediment hecho, respectivamente, por DelValls et al. $(1996,1997,1998 \mathrm{a}, \mathrm{b}, \mathrm{c})$ y por Chapman et al. (1987). El sedimento "limpio" (CN) fue utilizado para ambos estudios en los tests de toxicidad como control negativo (fig. 2), junto con muestras de agua oceánica. También se utilizó un control positivo en los ensayos realizados en el Golfo de Cádiz, siendo sedimento "polucionado" (CP), recolectado en el punto de vertido de aguas residuales no tratadas y localizado en la ciudad de San Fernando (fig. 2), así como el agua intersticial extraída de ellos.

\section{Componentes del sediment quality triad}

La serie de variables seleccionadas en ambos estudios y para cada componente se muestra brevemente en la figura 5. Los datos fueron analizados por un análisis estadistico multivariante (análisis de factores, utilizando como método de extracción el PCA), que explora la distribución de las variables (para el Golfo de Cádiz, concentraciones de contaminantes $n=$ 17 y efectos biológicos $n=10$; para la Bahía de San Francisco, concentraciones de contaminantes $n=18$ y efectos biológicos $n=12$ ). Este modelo de aproximación envuelve la investigación de las relaciones potenciales multidimensionales entre valores de datos químicos y efectos biológicos, y fue seguido mediante la clasificación de las muestras en grupos, cuando éstos pudiesen ser identificados. El PCA es una técnica que, aplicada al análisis de factores, es usada para reducir la dimensión de la serie de variables originales de una manera distinta. EI objetivo del PCA-factor es derivar un número reducido de nuevos factores que son una combinación lineal de las variables originales, las cuales producirán una descripción de la estructura de los datos con una pérdida mínima de información. El análisis de factores fue llevado a cabo sobre la matriz de correlación, i.e., las variables fueron autoescaladas (estandarizadas) para ser consideradas de igual importancia. Todos los análisis fueron realizados utilizando la opción PCA del procedimiento FACTOR, seguido por el procedimiento básico para un caso de análisis de factores (P4M) utilizando el paquete estadístico informático BMDP (Frane et al., 1985). La 


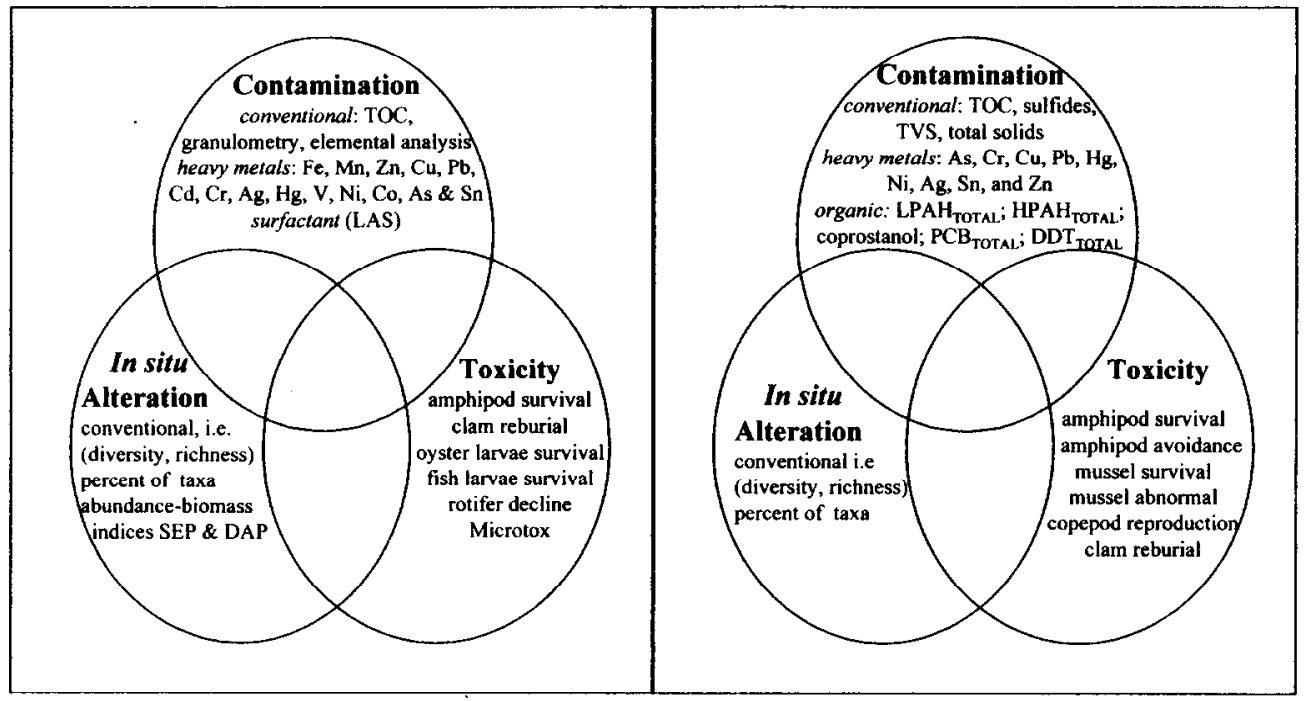

Figure 5. Schematic and summarized description of the methods used to evaluate the sediment quality triad in the Gulf of Cádiz (adapted from DelValls et al., 1998a) and in San Francisco Bay (adapted from Chapman et al., 1987).

Figura 5. Descripción resumida y esquemática de los métodos usados para evaluar el sediment quality triad en el Golfo de Cádiz (adaptada de DelValls et al., 1998a) y en la Bahía de San Francisco (adaptada de Chapman et al., 1987).

toxicity test endpoints (IC50 $0^{-1}$, defined as the inverse of the percentage of interstitial water causing a $50 \%$ inhibition of bioluminescence in the Microtox assay; ET50, defined as the time required for the burial of $50 \%$ of the population in the clam reburial assay; death after 10 days in the amphipod test; death after $48 \mathrm{~h}$ in the fish and bivalve larvae tests; and TL50 ${ }^{-1}$, defined as the inverse of the time required for $50 \%$ of the population to decline in the 7-day rotifer decline test) and four descriptive parameters of the macrobenthic infaunal community structure (richness ${ }^{-1}$, total abundance ${ }^{-1}$, $\%$ Polychaeta and diversity ${ }^{-1}$ [Shannon-Weaver diversity index, $H]$ ). The biological data sets were transformed to show an increase with biological damage. For example, the time required for $50 \%$ of the population to decline (TL50) increases when toxicity decreases; for this reason, some parameters calculated from the información del tipo de matriz sedimentaria, de la concentración de contaminantes, de las respuestas obtenidas en los ensayos de toxicidad, de los parámetros de la estructura de la comunidad bentónica y de las estaciones muestreadas fue usada para interpretar las tendencias de la serie de datos.

La base de datos contenía información de las muestras obtenidas en siete estaciones en el Golfo de Cádiz (fig. 5). La serie de datos de contaminantes incluía la concentración de 14 metales pesados, alquilbencenosulfonato lincal (LAS) y carbono orgánico (TOC), así como la superficie específica $(\sigma)$. Los efectos biológicos estaban determinados por seis respuestas de seis ensayos de toxicidad (IC50 ${ }^{-1}$, definido como la inversa del porcentaje de agua intersticial que causa una inhibición del $50 \%$ de la bioluminiscencia en el ensayo Microtox; ET50, definido como el tiempo requerido para que el 
toxicity tests and from the in situ biological effects were transformed as the inverse (TL50-1, $\mathrm{IC} \mathrm{O}^{-1}$, richness ${ }^{-1}$, total abundance ${ }^{-1}$ and diversity $^{-1}$ ), which in this form increases as the biological effect increases. All biological data were treated similarly, assuming equal significance for each type of toxicity test and descriptive parameter of the community structure.

In San Francisco Bay, the data base used was (fig. 5): sediment chemical data for nine heavy metals, low and high molecular weight aromatic hydrocarbons (LPAH and HPAH), total coprostanol, total DDTs and total PCBs; also, conventional parameters such as organic carbon (TOC), sulfide and total volatile solids (TVS). Biological effect data were provided by four sediment toxicity tests with six endpoints (ET50, clam reburial assay; death after 10 days and daily avoidance, amphipod test; death and percent abnormal after $48 \mathrm{~h}$, bivalve larvae test and percent of young produced per adults over four weeks, copepod test) and six descriptive parameters of the macrobenthic infaunal community structure (richness $^{-1}$, total abundance ${ }^{-1}$, numerical dominance, \% Amphipoda, \% Mollusca, \% Polychaeta). All biological data were treated similarly, assuming equal significance for each type of toxicity test and descriptive parameter of the community structure.

\section{RESULTS}

The summarized results of all SQT measurements are given in table $\mathbf{l}$ for the Gulf of Cádiz and in table 2 for San Francisco Bay. In order to establish the levels of adverse effects of contaminant concentrations in sediments, we applied a multivariate analysis (PCA-factor). The results of the multivariate statistical analysis are shown in table 3 for the Gulf of Cádiz and in tablc 4 for San Francisco Bay.

\section{Gulf of Cádiz}

The application of the factor analysis to the variables described above indicates that 24 variables (chemical concentrations in sediment and biological effects) can be represented by five new variables, or principal factors. These
$50 \%$ de la población se entierre en el ensayo de enterramiento de almejas; muerte después de 10 días en el ensayo de anfipodos; muerte después de $48 \mathrm{~h}$ en los ensayos de larvas de pez y bivalvo; y TL50 ${ }^{-1}$, definido como la inversa del tiempo requerido para que decaiga el $50 \%$ de la población de rotíferos en el ensayo de decaimiento de la población de rotíferos después de siete días); y cuatro parámetros descriptivos de la estructura de la comunidad bentónica (riqueza $^{-1}$, abundancia total ${ }^{-1}, \%$ poliquetos y diversidad $^{-1}$ [índice de diversidad de ShannonWeaver, $H]$ ). La serie de datos biológicos se transforma para mostrar un aumento con cl daño biológico. Por ejemplo, en el ensayo de rotíferos, el tiempo requerido por el $50 \%$ de la población para decaer (TL50) aumenta cuando la toxicidad disminuye; por esta razón, los parámetros fueron recalculados para algunos tests de toxicidad y para algunos parámetros descriptivos de la comunidad bentónica, transformándolos en su inversa (TL50 ${ }^{-1}$, IC $50^{-1}$, riqueza ${ }^{-1}$, abundancia total ${ }^{-1}$ y diversidad ${ }^{-1}$ ) y de esta forma aumentan cuando el efecto biológico lo hace. Todos los datos biológicos fueron tratados de forma similar, asumiendo un nivel de significación igual para cada tipo de test de toxicidad y para cada parámetro descriptivo de la comunidad bentónica.

En la Bahía de San Francisco, la base de datos utilizada fue (fig. 5): concentraciones en sedimento de nueve metales pesados, hidrocarburos aromáticos de alto y bajo peso molecular (HPAH y LPAH), coprostanol total, DDTs totales y PCBs totales; también, concentraciones de parámetros convencionales como carbono orgánico (TOC), sulfuros y sólidos volátiles totales (TVS). Los datos correspondientes al efecto biológico fueron obtenidos a partir de seis respuestas medidas en cuatro tests de toxicidad (ET50, ensayo de enterramiento de almejas, muerte después de 10 días y huida diaria, ensayo con anfipodos; muerte y porcentaje de anormalidad después de $48 \mathrm{~h}$, ensayo con larvas de bivalvo; y porcentaje de jóvenes producidos por adulto durante las cuatro semanas de duración, ensayo con copépodos) y seis parámetros descriptivos de la estructura de la comunidad bentónica (riqueza ${ }^{-1}$, abundancia total $^{-1}$, dominancia numérica, $\%$ anfípodos, 
new factors explain $96.51 \%$ of the variance in the original data set. The sorted rotated factor loadings (pattern) are coefficients correlating the original variables and the principal factors in this analysis. The variables are reordered so that the rotated factor loadings for each factor are clustered together. In the present study, we elected to interpret a variable or group of variables as those associated with a particular factor where loadings were 0.4 or greater (table 3), corresponding to an associated explained variance of over $65 \%$. This approximates Comrey's (1973) cut-off of 0.55 for a good association between an original variable and a factor, and also takes into account discontinuities in the magnitudes of loadings in the original variables. Negative values of sorted rotated factor loadings (negative salience) are as important as positive values (positive salience); however, in this analysis, the positive loadings are in general of larger magnitude than the negative loadings (only $\mathrm{Mn}$ and mortality of Sparus aurata larvae [factor3] and Cd [factor 4] were negative).

The loadings following varimax rotation for the five factors are given in table 3. Each factor is described according to the dominant group of variables:

- The first principal factor, \#1, is predominant and accounts for $42.61 \%$ of the variance. This factor combines the chemical concentrations of LAS, $\mathrm{Pb}, \mathrm{Ag}$ and organic carbon in sediments and the adverse effects measured by the parameters IC $50^{-1}$, ET50, amphipod mortality, total abundance $\mathrm{e}^{-1}, \mathrm{Bi}-$ valvia mortality, fish mortality and $\mathrm{TL}^{-1} 0^{-1}$. It represents biological effects associated with chemicals from urban sources.

- The second factor, $\# 2$, accounts for $21.61 \%$ of the variance and combines seven heavy metals (Co, Fe, Ni, V, Zn, $\mathrm{Cu}$ and $\mathrm{Mn}$ ), organic carbon, and the specific surface $(\sigma)$. It represents a natural sedimentary matrix at the study site.

- The third factor, \#3, accounts for $16.30 \%$ of the variance and is a combination of five original variables: three positive,
$\%$ moluscos y $\%$ poliquetos). Todos los datos biológicos fueron tratados de forma similar, asumiendo un nivel de significación igual para cada tipo de test de toxicidad y cada parámetro descriptivo de la comunidad bentónica.

\section{RESULTADOS}

El resumen de los resultados obtenidos se ofrece en la tabla 1 para el Golfo de Cádiz y en la tabla 2 para la Rahía de San Francisco. Con el objetivo de establecer los niveles de efecto biológico asociados con las concentraciones encontradas en los sedimentos, se aplicó el análisis multivariante (PCA-factor). Los resultados obtenidos del análisis multivariante se muestran en la tabla 3 para el Golfo de Cádiz y en la tabla 4 para la Bahía de San Francisco.

\section{Golfo de Cádiz}

La aplicación del análisis de factores a las variables descritas arriba indica que las 24 variables (concentraciones químicas en sedimento y efectos biológicos) pueden ser representadas por cinco variables nuevas, o factores principales. Estos factores nuevos explican el $96.51 \%$ de la varianza en la serie de datos originales. Los pesos de los factores rotados son coeficientes que correlacionan las variables originales y los factores en este análisis. Las variables son reordenadas; por lo tanto, los pesos de los factores rotados para cada factor son colocados juntos en forma de racimo. En el presente estudio, para agrupar una variable dentro de un determinado factor se selecciona ésta cuando su peso es 0.4 o mayor (tabla 3 ), correspondiendo a una varianza explicada de más del $65 \%$. Esto aproxima al corte de Comrey (1973) de 0.55 para una buena asociación entre una variable original y un factor, y también tiene en cuenta las discontinuidades en las magnitudes de los pesos en las variables originales. Los valores negativos de estos pesos en los factores rotados son tan importantes como los valores positivos. Sin embargo, en este análisis, los pesos positivos son en general de mayor magnitud que los pesos negalivos (sólo Mn y mortalidad de larvas de Sparus aurata [factor 3] y Cd [factor 4] fueron negativos). 
Table 1. Summary of the results obtained for the sediment quality triad in the Gulf of Cádiz (adapted from DelValls et al., 1998a). The units ppm and \% are related to dry weight sediment.

Tabla 1. Resumen de los resultados obtenidos en la aplicación del método sediment quality triad en el Golfo de Cádiz (adaptada de DelValls et al, 1998a). Las unidades ppm y \% hacen referencia a peso seco de sedimento.

\begin{tabular}{lccccccc} 
Variables & CB1 & CB2 & CB3 & CB4 & CB5 & BR1 & BR2 \\
\hline Chemicals & & & & & & & \\
TOC $(\%)$ & & & & & & & \\
$\sigma\left(\mathrm{m}^{2} \mathrm{~cm}^{-3}\right)$ & 1.39 & 2.96 & 2.21 & 1.82 & 2.46 & 0.59 & 1.86 \\
Fe (\%) & 7.63 & 7.35 & 7.96 & 7.16 & 7.03 & 5.78 & 7.77 \\
Mn (ppm) & 2.77 & 3.34 & 3.19 & 3.34 & 2.77 & 1.27 & 3.98 \\
$\mathrm{Zn}(\mathrm{ppm})$ & 333 & 278 & 332 & 452 & 272 & 262 & 295 \\
$\mathrm{Cu}(\mathrm{ppm})$ & 82 & 157 & 163 & 73 & 105 & 34 & 140 \\
$\mathrm{~Pb}(\mathrm{ppm})$ & 51.4 & 69.6 & 66.4 & 34.8 & 49.6 & 37.4 & 73.7 \\
$\mathrm{Cd}(\mathrm{ppm})$ & 30.5 & 84.6 & 64.4 & 24.4 & 51.1 & 66.8 & 30.0 \\
$\mathrm{Cr}(\mathrm{ppm})$ & 0.51 & 0.67 & 0.75 & 0.99 & 0.81 & 1.10 & 0.68 \\
$\mathrm{Ag}(\mathrm{ppm})$ & 49.6 & 77.1 & 53.0 & 41.1 & 283.9 & 42.5 & 101.2 \\
$\mathrm{Hg}(\mathrm{ppm})$ & 0.48 & 1.34 & 1.20 & 0.78 & 1.06 & 0.75 & 0.61 \\
$\mathrm{~V}(\mathrm{ppm})$ & 0.11 & 0.25 & 0.46 & 0.25 & 0.57 & 0.06 & 0.15 \\
$\mathrm{Ni}(\mathrm{ppm})$ & 79.1 & 106.5 & 77.0 & 80.7 & 83.3 & 17.9 & 147.5 \\
$\mathrm{Co}(\mathrm{ppm})$ & 24.9 & 35.5 & 27.9 & 34.4 & 32.5 & 8.2 & 42.8 \\
$\mathrm{As}(\mathrm{ppm})$ & 7.29 & 9.16 & 7.64 & 10.92 & 7.78 & 3.40 & 11.50 \\
$\mathrm{Sn}(\mathrm{ppm})$ & 11.27 & 7.72 & 13.69 & 8.53 & 13.24 & 5.19 & 9.67 \\
$\mathrm{LAS}(\mathrm{ppm})$ & 19.8 & 17.0 & 24.0 & 9.9 & 18.8 & 7.4 & 10.3 \\
& 2.2 & 62.1 & 12.8 & 2.6 & 1.2 & 1.7 & 2.5
\end{tabular}

\section{Toxicity tests}

$\begin{array}{lccllccc}\text { Amphipod mortality (\%) } & 15.0 & 82.5 & 32.5 & 22.5 & 47.5 & 22.5 & 20 \\ \text { Clam reburial (ET50 [h]) } & 5.60 & >48 & 11.60 & 10.78 & 8.66 & 0.98 & 2.80 \\ \text { Fish mortality (\%) } & 74.5 & 99.0 & 91.8 & 73.7 & 78.6 & 29.6 & 33.7 \\ \text { Oyster mortality (\%) } & 18.0 & 82.3 & 55.8 & 17.2 & 47.5 & 6.0 & 7.1 \\ \text { Rotifer decline (TL50 [h]) } & 55.5 & 38.4 & 42.3 & 55.4 & 37.5 & 52.5 & 53.6 \\ \text { Microtox (IC50) } & >100 & 4.5 & >100 & >100 & >100 & >100 & >100 \\ & & & & & & & \\ \text { Infaunal parameters } & & & & & & & \\ \text { Total abundance } & 39 & 2 & 37 & 35 & 9 & 11 & 7 \\ \text { Diversity } & 2.214 & 0.693 & 1.429 & 2.059 & 1.503 & 0.260 & 0.573 \\ \text { Richness } & 4.86 & 1.44 & 4.43 & 5.46 & 1.65 & 1.20 & 0.73 \\ \text { \% Polychaeta } & 38 & 100 & 95 & 53 & 84 & 100 & 100\end{array}$


Table 2. Summary of the results obtained for the sediment quality triad in San Francisco Bay (adapted from Chapman et al., 1987). The units ppb, ppm and \% are related to dry weight sediment.

Tabla 2. Resumen de los resultados obtenidos en la aplicación del método sediment quality triad en la Bahía de San Francisco (adaptada de Chapman et al., 1987). Las unidades ppm, ppb y \% hacen referencia a peso seco de sedimento

\begin{tabular}{|c|c|c|c|c|c|c|c|c|c|}
\hline Variable & SP02 & SP05 & SP09 & OA02 & OA05 & OA09 & ISO2 & IS05 & IS09 \\
\hline \multicolumn{10}{|l|}{ Chemicals } \\
\hline $\operatorname{TOC}(\%)$ & 0.60 & 1.25 & 1.46 & 1.31 & 1.10 & 1.24 & 4.03 & 3.14 & 1.44 \\
\hline Sulfide (ppm) & 89 & 5.0 & 5.0 & 9.3 & 5.0 & 5.0 & 740 & 620 & 260 \\
\hline TVS (\%) & 4.0 & 6.6 & 7.2 & 7.9 & 6.7 & 6.8 & 12.8 & 11.4 & 9.4 \\
\hline Solids (\%) & 61.3 & 44.9 & 42.9 & 38.0 & 41.4 & 37.1 & 31.7 & 33.3 & 34.9 \\
\hline As (ppm) & 44 & 54 & 70 & 64 & 58 & 49 & 57 & 66 & 72 \\
\hline $\mathrm{Cr}(\mathrm{ppm})$ & 72 & 86 & 93 & 95 & 85 & 90 & 134 & 146 & 110 \\
\hline $\mathrm{Cu}(\mathrm{ppm})$ & 30 & 49 & 53 & 51 & 43 & 45 & 130 & 98 & 68 \\
\hline $\mathrm{Pb}(\mathrm{ppm})$ & 18 & 21 & 25 & 33 & 29 & 30 & 223 & 115 & 49 \\
\hline $\mathrm{Hg}(\mathrm{ppm})$ & 0.09 & 0.24 & 0.31 & 0.28 & 0.21 & 0.29 & 0.57 & 1.2 & 0.37 \\
\hline $\mathrm{Ni}(\mathrm{ppm})$ & 76 & 83 & 85 & 84 & 72 & 76 & 94 & 96 & 88 \\
\hline $\mathrm{Ag}(\mathrm{ppm})$ & 0.9 & 1.1 & 1.6 & 2.0 & 1.7 & 2.4 & 8.1 & 8.6 & 4.0 \\
\hline Sn (ppm) & 3.0 & 5.4 & 4.5 & 5.3 & 5.4 & 6.5 & 17 & 15 & 8.0 \\
\hline $\mathrm{Zn}(\mathrm{ppm})$ & 86 & 107 & 114 & 122 & 102 & 109 & 321 & 225 & 156 \\
\hline $\mathrm{LPAH}_{\text {Total }}(\mathrm{ppm})$ & 0.03 & 0.21 & 0.22 & 0.43 & 0.4 & 0.32 & 3.16 & 2.76 & 0.92 \\
\hline $\mathrm{HPAH}_{\text {Total }}(\mathrm{ppm})$ & 0.22 & 0.85 & 0.67 & 1.89 & 1.53 & 1.11 & 12.06 & 11.83 & 4.48 \\
\hline Coprostanol $_{\text {Total }}(\mathrm{ppm})$ & 0.16 & 0.53 & 0.75 & 0.83 & 1.42 & 0.28 & 31.55 & 26.11 & 5.45 \\
\hline $\mathrm{DDT}_{\text {Total }}(\mathrm{ppb})$ & 0.42 & 0.8 & 0.71 & 1.53 & 1.06 & 0.78 & 2.93 & 3.6 & 2.24 \\
\hline $\mathrm{PCB}_{\text {Tolal }}(\mathrm{ppb})$ & 5.7 & 11.1 & 17.5 & 36.8 & 26.6 & 27 & 179.8 & 255.3 & 57.3 \\
\hline \multicolumn{10}{|l|}{ Toxicity tests } \\
\hline \multicolumn{10}{|l|}{ Amphipod } \\
\hline Mortality (\%) & 9 & 4 & 24 & 9 & 13 & 13 & 95 & 24 & 37 \\
\hline Avoidance $(\%)$ & 1.1 & 0.5 & 0.5 & 0.7 & 0.4 & 1.9 & 7.4 & 1.7 & 0.6 \\
\hline \multicolumn{10}{|l|}{ Mussel larvae } \\
\hline Abnormality $(\%)$ & 13.4 & 7.7 & 15.3 & 14.5 & 24.7 & 18.7 & 67.7 & 65.9 & 31.9 \\
\hline Mortality (\%) & 43.1 & 17.3 & 49.1 & 50.9 & 76.0 & 66.5 & 94.0 & 96.8 & 86.1 \\
\hline \multicolumn{10}{|l|}{ Clam } \\
\hline $\operatorname{ET50}(\mathrm{h})$ & 3.3 & 3.9 & 3.2 & 3.6 & 3.9 & 5.8 & 7.5 & 7.0 & 4.0 \\
\hline \multicolumn{10}{|l|}{ Copepod } \\
\hline Reproduction (\%) & 0.406 & 0.330 & 0.652 & 0.381 & 0.371 & 0.344 & 0.465 & 50.536 & 0.652 \\
\hline \multicolumn{10}{|l|}{ Infaunal parameters } \\
\hline Richness & 6.6 & 9.8 & 14.4 & 12.6 & 14.2 & 16.6 & 2.4 & 2.0 & 8.2 \\
\hline 'otal abundance & 637 & 374 & 816 & 3024 & 3788 & 3694 & 47 & 59 & 15 \\
\hline Numerical dominance & 0.68 & 0.75 & 0.84 & 0.88 & 0.85 & 0.85 & 0.62 & 0.65 & 0.08 \\
\hline$\%$ Amphipoda & 85 & 83 & 87 & 84 & 85 & 86 & 10 & 7 & 15 \\
\hline$\%$ Polychaeta & 10 & 11 & 9 & 11 & 12 & 13 & 89 & 92 & 55 \\
\hline \% Mollusca & 5 & 6 & 4 & 5 & 3 & 1 & 1 & 1 & 30 \\
\hline
\end{tabular}


Table 3. Sorted rotated factor loadings (pattern) of 27 variables for the five principal factors resulting from the multivariate analysis in the Gulf of Cádiz. The loading matrix has been arranged so that the columns appear in decreasing order of variance explained by factors. Only loadings greater than 0.4 are shown in the table. Factors (\#) are numbered consecutively from left to right in order of decreasing variance.

Tabla 3. Pesos de los factores rotados de 27 variables en los cinco factores principales obtenidos del análisis sobre los datos obtenidos en el Golfo de Cádiz. La matriz de los pesos ha sido ordenada de forma que en las columnas aparecen en orden de varianza decreciente explicada. Sólo los pesos mayores que 0.4 se muestran en la tabla. Los factores (\#) están numerados consecutivamente de izquierda a derecha a medida que explican menor varianza.

\begin{tabular}{|c|c|c|c|c|c|}
\hline $\begin{array}{l}\text { Variables } \\
\% \text { variance }\end{array}$ & $\begin{array}{c}\# 1 \\
42.61\end{array}$ & $\begin{array}{c}\# 2 \\
21.61\end{array}$ & $\begin{array}{c}\# 3 \\
16.30\end{array}$ & $\begin{array}{c}\# 4 \\
9.98\end{array}$ & $\begin{array}{c}\# 5 \\
6.28\end{array}$ \\
\hline $\operatorname{IC50}\left(\% \%^{-1}\right)$ & 0.982 & -- & --- & --- & -- \\
\hline $\operatorname{ET50}(\mathrm{h})$ & 0.973 & --- & $-\cdots$ & --- & --- \\
\hline LAS (ppm) & 0.972 & --- & --- & --- & --- \\
\hline Amphipod mortality (\%) & 0.938 & $--\cdot$ & --- & --- & --- \\
\hline Total abundance $^{-1}$ & 0.934 & --- & -- & --- & --- \\
\hline Oyster mortality (\%) & 0.792 & -- & --- & -- & --- \\
\hline $\mathrm{Pb}(\mathrm{ppm})$ & 0.744 & -- & --- & --- & -- \\
\hline $\mathrm{Ag}(\mathrm{ppm})$ & 0.729 & --- & --- & --- & $-\cdots$ \\
\hline $\operatorname{TOC}(\%)$ & 0.625 & 0.532 & --- & $\cdots$ & 0.461 \\
\hline Co (ppm) & -- & 0.992 & --- & --- & --- \\
\hline $\mathrm{Fe}(\mathrm{ppm})$ & -- & 0.959 &.-- & --- & -- \\
\hline $\mathrm{Ni}(\mathrm{ppm})$ & --- & 0.955 & -- & --- & --- \\
\hline $\mathrm{V}(\mathrm{ppm})$ & $\cdots$ & 0.907 & --- & --- & --- \\
\hline$\sigma\left(\mathrm{m}^{2} \mathrm{~cm}^{-3}\right)$ & -- & 0.674 & --- & 0.650 & --- \\
\hline Richness $^{-1}$ & --- & -- & 0.964 & --- & --- \\
\hline $\mathrm{Mn}(\mathrm{ppm})$ & $\cdots$ & 0.421 & -0.754 & --- & --- \\
\hline Fish mortality (\%) & 0.521 & -- & -0.746 & -- & -- \\
\hline$\%$ Polychaeta & -- & --- & 0.703 & -- & --- \\
\hline Diversity $^{-1}$ & -- & -- & 0.682 & -- & --- \\
\hline $\mathrm{Cd}(\mathrm{ppm})$ & --- & --- & -- & -0.842 & --- \\
\hline $\mathrm{Sn}(\mathrm{ppm})$ & --- & --- & --- & 0.633 & --- \\
\hline $\mathrm{Cu}(\mathrm{ppm})$ & -- & 0.473 & -- & 0.663 & --- \\
\hline As (ppm) & -- & --- & -- & 0.633 & 0.572 \\
\hline $\mathrm{Zn}(\mathrm{ppm})$ & --- & 0.550 & --- & 0.582 & -- \\
\hline $\mathrm{Cr}(\mathrm{ppm})$ & --- & --- & --- & --- & 0.963 \\
\hline $\mathrm{Hg}(\mathrm{ppm})$ & -- & --- & -- & --- & 0.839 \\
\hline $\operatorname{TL50}\left(\mathrm{h}^{-1}\right)$ & 0.608 & $\cdots$ & --- & --- & 0.738 \\
\hline
\end{tabular}


Table 4. Sorted rotated factor loadings (pattern) of 30 variables for the four principal factors resulting from the multivariate analysis in San Francisco Bay. The loading matrix has been arranged so that the columns appear in decreasing order of variance explained by factors. Only loadings greater than 0.4 are shown in the table. Factors (\#) are numbered consecutively from left to right in order of decreasing variance.

Tabla 4. Pesos de los factores rotados de 30 variables en los cuatro factores principales obtenidos del análisis sobre los datos obtenidos en la Bahía de San Francisco. La matriz de los pesos ha sido ordenada de forma que en las columnas aparecen en orden de varianza decreciente explicada. Sólo los pesos mayores que 0.4 se muestran en la tabla. Los factores (\#) están numerados consecutivamente de izquierda a derecha a medida que explican menos varianza.

\begin{tabular}{|c|c|c|c|c|}
\hline $\begin{array}{l}\text { Variables } \\
\% \text { variance }\end{array}$ & $\begin{array}{c}\# 1 \\
69.35\end{array}$ & $\begin{array}{c}\# 2 \\
12.51\end{array}$ & $\begin{array}{c}\# 3 \\
5.45\end{array}$ & $\begin{array}{c}\# 4 \\
3.66\end{array}$ \\
\hline $\mathrm{Hg}(\mathrm{ppm})$ & 0.935 & -- & -- & --- \\
\hline $\mathrm{PCB}_{\text {Total }}(\mathrm{ppm})$ & 0.929 & $-\cdots$ & --- & --- \\
\hline Richness $^{-1}$ & 0.914 & -- & --- & --- \\
\hline$\%$ Amphipoda $^{-1}$ & 0.908 & --- & --- & --- \\
\hline $\mathrm{Ag}(\mathrm{ppm})$ & 0.851 & --- & 0.431 & --- \\
\hline $\mathrm{HPAH}_{\text {Total }}(\mathrm{ppm})$ & 0.840 & --- & 0.466 & --- \\
\hline $\mathrm{DDT}_{\text {Total }}(\mathrm{ppm})$ & 0.837 & -- & -- & --- \\
\hline $\mathrm{Cr}(\mathrm{ppm})$ & 0.832 & -- & 0.350 & 0.347 \\
\hline$\%$ Polychaeta & 0.829 & -- & 0.418 & --- \\
\hline Mussel abnormality (\%) & 0.823 & -- & 0.474 & --- \\
\hline $\mathrm{LPAH}_{\text {rotal }}(\mathrm{ppm})$ & 0.807 & -- & 0.532 & --- \\
\hline Coprostanol $_{\text {Total }}(\mathrm{ppm})$ & 0.803 & --- & 0.544 & -- \\
\hline Sulfide (ppm) & 0.800 & $\cdots$ & 0.519 & --- \\
\hline $\mathrm{Sn}(\mathrm{ppm})$ & 0.782 & --- & 0.558 & --- \\
\hline Clam ruburial (ET50) & 0.730 & $\cdots$ & 0.530 & --- \\
\hline $\operatorname{TOC}(\%)$ & 0.707 & -- & 0.628 & --- \\
\hline $\mathrm{Ni}(\mathrm{ppm})$ & 0.691 & --- & 0.307 & 0.388 \\
\hline $\mathrm{Cu}(\mathrm{ppm})$ & 0.667 & $\cdots$ & 0.660 & --- \\
\hline $\operatorname{TVS}(\%)$ & 0.658 & -- & 0.554 & 0.425 \\
\hline $\mathrm{Zn}(\mathrm{ppm})$ & 0.650 & -- & 0.705 & --- \\
\hline Mussel mortality (\%) & 0.609 & --- & 0.360 & --- \\
\hline $\mathrm{Pb}(\mathrm{ppm})$ & 0.602 & $\cdots$ & 0.764 & --- \\
\hline Amphipod avoidance (\%) & 0.346 & $-\cdots$ & 0.897 & -- \\
\hline Amphipod mortality (\%) & 0.309 & --- & 0.881 & --- \\
\hline Numerical dominance ${ }^{-1}$ & -- & -0.952 & $-\cdots$ & --- \\
\hline$\%$ Mollusca & --- & 0.926 & --- & --- \\
\hline Total abundance ${ }^{-1}$ & $-\ldots$ & 0.909 & --- & -- \\
\hline Copepod reproduction (\%) & --- & 0.593 & -- & 0.519 \\
\hline As (ppm) & --- & --- & -- & 0.870 \\
\hline Solids $(\%)$ & --- & --- & -0.410 & -0.667 \\
\hline
\end{tabular}


corresponding to descriptive parameters of the infaunal community structure (richness ${ }^{-1}$, $\%$ Polychaeta and diversity ${ }^{-1}$ ); and two negative contributions of $\mathrm{Mn}$ concentration and fish mortality. These contributions represent natural variability in the macrobenthic infaunal community structure, with no chemical concentration correlation.

- Factor \#4 accounts for $9.98 \%$ of the variance; it identifies marine contamination phenomena not associated with adverse effects, and is a combination of five chemical concentrations in sediment ( $\mathrm{Sn}, \mathrm{Cu}, \mathrm{As}, \mathrm{Zn}$ and negative salience $\mathrm{Cd}$ ) and the specific surface $(\sigma)$.

- Factor \#5 accounts for $6.28 \%$ of the variance and identifies adverse effects of three chemical concentrations $(\mathrm{Cr}, \mathrm{Hg}$ and, slightly, As) in sediment of 7-day rotifer decay tests.

\section{San Francisco Bay}

The application of the factor analysis to the variables described above indicates that 30 variables (chemical concentrations in sediment and biological effects) can be represented by four new variables, or principal factors. These new factors explain $90.92 \%$ of the variance in the original data set. The sorted rotated factor loadings (pattern) and the variables were treated as for the Gulf of Cádiz data set.

The loadings following varimax rotation for the four factors are given in table 4. Each factor is described according to the dominant group of variables:

- The first principal factor, \#1, is predominant and accounts for $69.35 \%$ of the variance. This factor combines the chemical concentrations of $\mathrm{Hg}, \mathrm{PCB}_{\text {Total }}, \mathrm{Ag}, \mathrm{HPAH}_{\text {Total, }}$ $\mathrm{DDT}_{\text {Total }}, \mathrm{Cr}, \quad \mathrm{LPAH}_{\text {Total }}, \quad$ coprostanol $_{\text {Total }}$, sulfide, Sn, TOC, Ni, Cu, TVS, $\mathrm{Zn}$ and $\mathrm{Pb}$ in sediments and the adverse effects measured by the parameters richness ${ }^{-1}$, $\%$ Amphipoda $^{-1}$, \% Polychaeta, mussel abnormality, ET50, mussel mortality, amphipod avoidance and amphipod mortality. It represents biological effects associated with chemicals from different sources.
En la tabla 3 se muestran los pesos de las variables obtenidas siguiendo una rotación de varianza máxima para los cinco factores. Cada factor es descrito de acuerdo con el grupo dominante de variables:

- El primer factor, \#1, es el predominante y representa el $12.61 \%$ de la varianza. Este factor combina las concentraciones químicas en sedimento de $\mathrm{LAS}, \mathrm{Pb}, \mathrm{Ag}$ y carbono orgánico y el efecto adverso medido por los parámetros $\mathrm{IC} 50^{-1}$, ET50, mortalidad de anfipodos, abundancia total ${ }^{-1}$, mortalidad de bivalvos, mortalidad de peces y $\mathrm{IL}^{2} \mathrm{O}^{-1}$. Este factor representa los efectos biológicos asociados con contaminantes de origen urbano.

- El segundo factor, \#2, representa el $21.61 \%$ de la varianza y combina siete metales pesados ( $\mathrm{Co}, \mathrm{Fe}, \mathrm{Ni}, \mathrm{V}, \mathrm{Zn}, \mathrm{Cu}$ y $\mathrm{Mn}$ ), el carbono orgánico y la superficie específica $(\sigma)$. Esta asociación representa la matriz sedimentaria en la zona de estudio.

- El tercer factor, $\# 3$, representa el $16.30 \%$ de la varianza y es una combinación de cinco variables originales: tres positivas, correspondientes a los paránetros descriptivos de la comunidad bentónica (riqueza ${ }^{-1}$, \% poliquetos y diversidad ${ }^{-1}$ ); y dos contribuciones negativas, correspondientes a la concentración de Mn y a la mortalidad de peces. Estas contribuciones representan una variabilidad natural en la estructura de la comunidad bentónica, con ninguna correlación con las concentraciones de contaminantes en sedimento.

- El factor \#4 representa el $9.98 \%$ de la varianza e identifica fenómenos de contaminación marina no asociados con efectos biológicos, siendo una combinación de cinco concentraciones de contaminantes en sedimentos ( $\mathrm{Sn}, \mathrm{Cu}, \mathrm{As}, \mathrm{Zn} \mathrm{y,} \mathrm{con} \mathrm{peso} \mathrm{nega-}$ tivo, Cd) y la superficie especifica $(\sigma)$.

- El factor \#5 representa el $6.28 \%$ de la varianza e identifica el efecto adverso de tres concentraciones de contaminantes en sedimento ( $\mathrm{Cr}, \mathrm{Hg}$ y, en menor grado, As) con el ensayo de 7 días realizado sobre rotíferos. 
- The second factor, \#2, accounts for $12.51 \%$ and combines none of the chemical concentrations, but does include four biological responses: three in situ measurements (dominance $^{-1}$, \% Mollusca, abundance ${ }^{-1}$ ), and one toxicity test endpoint ( $\%$ copepod reproduction). It represents the biological variability that could be associated with the structure of macrobenthic communities.

- The third factor, \#3, accounts for $5.45 \%$ of the variance and is a combination of 20 original variables: $\mathrm{Ag}, \mathrm{HPAH}_{\text {Total, }} \mathrm{Cr}$, $\mathrm{LPAH}_{\text {Total }}$, coprostanol $_{\text {Total }}$, sulfide, Sn, TOC, $\mathrm{Ni}, \mathrm{Cu}, \mathrm{TVS}, \mathrm{Zn}, \mathrm{Pb}$ and solids in sediments and the adverse effects measured by the parameters \% Polychaeta, mussel abnormality, ET50, mussel mortality, amphipod avoidance and amphipod mortality. All of them were included in the first factor. The principal difference in this association of original variables is related to the higher contribution of the amphipod endpoints (avoidance and mortality) to this variable than to the first one. These contributions could represent chemical effects to the specific amphipod endpoints. Because of the lower variance associated with this factor $(5.45 \%)$, this interpretation must be taken with caution.

- The lowest eigenvalue factor, \#4, accounts for $3.66 \%$ of the variance and gives high loadings on As and copepod reproduction, and negative on solids, being lower for TVS, $\mathrm{Ni}$ and $\mathrm{Cr}$. It could represent the relationships between the arsenic concentration in sediment and the biological effect measured on copepods, but due to the lowest variance, the interpretation of the associations found in this factor may not be highly significant.

After analyzing the above factor descriptions, we propose that, of the chemicals measured in the Gulf of Cádiz, the principal contaminants that are stressing the benthic ecosystems are: from factor 1 , high levels of $\mathrm{Pb}$, $\mathrm{Ag}$ and LAS, measured in sediments from station $\mathrm{CB} 2$; and from factor 5 , high levels of dissolved $\mathrm{Cr}$ and $\mathrm{Hg}$ in the interstitial water obtained from sediments at different stations, being more clear at station CB5.

\section{Bahía de San Francisco}

La aplicación del análisis de factores a las variables descritas anteriormente indica que las 30 variables (concentraciones químicas en sedimento y efectos biológicos) pueden ser representadas por cuatro variables nuevas, o factores principales. Estos factores nuevos explican el $90.92 \%$ de la varianza en la serie de datos originales. Los pesos de los factores y las variables fueron tratados de forma similar a como se describió anteriormente para el caso del Golfo de Cádiz.

En la tabla 4 se muestran los pesos de las variables obtenidas siguiendo una rotación de varianza máxima para los cuatro factores. Cada factor es descrito de acuerdo con el grupo dominante de variables:

- El primer factor, \#1, es el predominante y representa el $69.35 \%$ de la varianza. Este factor combina las concentraciones químicas en sedimento de $\mathrm{Hg}, \mathrm{PCB}_{\text {Total }}, \mathrm{Ag}, \mathrm{HPAH}_{\text {Total }}$, $\mathrm{DDT}_{\text {Tolal }}, \quad \mathrm{Cr}, \mathrm{LPAH}_{\text {Total }}$, coprostanol $_{\text {Tolal }}$, sulfuros, $\mathrm{Sn}, \mathrm{TOC}, \mathrm{Ni}, \mathrm{Cu}$, TVS, $\mathrm{Zn}$ y $\mathrm{Pb}$; y el efecto adverso medido por los parámetros riqueza ${ }^{-1}, \%$ anfípodos ${ }^{-1}, \%$ poliquetos, anormalidad de moluscos, ET50, mortalidad de anfipodos, huida de anfipodos y mortalidad de anfipodos. Este factor representa los efectos biológicos asociados con contaminantes de diversos orígenes.

- El segundo factor, \#2, representa el $12.51 \%$ de la varianza y no combina concentraciones de contaminantes en sedimento, pero incluye relaciones entre cuatro de los efectos medidos (dominancia ${ }^{-1}, \%$ moluscos, abundancia $^{-1}$ ) y una de las respuestas de los tests de toxicidad. Esta asociación representa variabilidad biológica, que podría ser asociada con la estructura de las comunidades bentónicas.

- El tercer factor, \#3, representa el $5.45 \%$ de la varianza y es una combinación de 20 variables originales: concentraciones en sedimento de $\mathrm{Ag}, \mathrm{HPAH}_{\text {Total }}, \mathrm{Cr}, \mathrm{LPAH}_{\text {Total, }}$ coprostanol $_{\text {Tolal }}$, sulfuros, $\mathrm{Sn}, \mathrm{TOC}, \mathrm{Ni}, \mathrm{Cu}$, TVS, $\mathrm{Zn}, \mathrm{Pb}$, y sólidos y el efecto adverso medido por los parámetros $\%$ poliquetos, 
For San Francisco Bay, we propose that the principal contaminants stressing the benthic ecosystems are: from factor $1, \mathrm{Hg}, \mathrm{PCB}_{\text {Total, }}, \mathrm{Ag}$, $\mathrm{DDT}_{\text {Total }}, \mathrm{Cr}, \mathrm{Sn}, \mathrm{Ni}, \mathrm{Cu}, \mathrm{Zn}$ and $\mathrm{Pb}$, measured in sediments from the Islais Waterways sample sites; and from factor 4, As measured in sediments from stations SP09 and OA02.

\section{DISCUSSION}

In order to confirm these factor descriptions and to establish the site-specific values of sediment quality in the ecosystems studied here (Gulf of Cádiz and San rrancisco Bay), we propose a representation of the factor scores estimated for each case (stations) to the centroid of all cases for the original data (fig. 6 for the Gulf of Cádiz and fig. 7 for San Francisco Bay). We used the prevalence (factor scores) of principal factors for each of the cases studied to make the next three operative definitions based on the data obtained from the SQT. When the factor scores (F1 and $\mathrm{F} 5$ ) from factors \#1 and \#5 of the Gulf of Cádiz and the factor scores (F1, F3, and F4) from factors $\# 1, \# 3$ and $\# 4$ of San Francisco Bay, which are factors showing relationships between groups of chemicals and adverse effects, are both zero or below with respect to all the cases, the maximum concentrations of toxic chemicals at any of those stations represent the maximum chemical concentrations not associated with adverse effects. These are considered to be chemical concentrations below which biological effect levels are low or minimal and are described here as "no or minimal adverse biological effects". In contrast, to establish the minimal concentrations above which biological effects are always high, the minimal concentrations at the stations where the factor scores mentioned (F1 and F2 in the Gulf of Cádiz and F1, F3 and F4 in San Francisco Bay) are higher than zero were selected and described here as "major adverse biological effects". An intermediate range of chemical concentrations representing an "area of uncertainty", or a break point between the high and low concentrations, is also defined.

The site-specific values (SQV) proposed for the five different chemicals ( $\mathrm{LAS}, \mathrm{Pb}, \mathrm{Ag}, \mathrm{Cr}$ and $\mathrm{Hg}$ ) in the Gulf of Cádiz according to these anormalidad de bivalvos, ET50, mortalidad de bivalvos, huida de anfípodos y mortalidad de anfípodos. Todas estas variables están también incluidas en el primer factor. La diferencia principal entre ambas asociaciones radica en la mayor contribución de las respuestas medidas en el ensayo de anfipodos (huida y mortalidad) en este factor que en el factor \#1. Estas contribuciones podrian representar efectos químicos sobre las respuestas especificas medidas en el ensayo de anfipodos. Debido a la baja varianza explicada por este factor $(5.45 \%)$, esta interpretación debe ser tomada con precaución.

- La más baja de las contribuciones de los factores es la asociada con el factor \#4 (3.66\%), que incluye pesos positivos altos de las variables As y reproducción de copépodos, y negativos de los sólidos, siendo menores para TVS, Ni y Cr. Esta asociación podría representar una relación entre las concentraciones de arsénico en sedimentos y el efecto biológico medido en copépodos, pero debido a que representa la más baja de las varianzas, la interpretación de las asociaciones encontradas en este factor podría no ser altamente significativa.

Basándonos en los resultados del análisis de factores mostrado arriba, proponemos que de aquellos contaminantes medidos en el Golfo de Cádiz, los que son fuente de estrés en el ecosistema son: del factor 1 , niveles altos de $\mathrm{Pb}, \mathrm{Ag}$ y LAS, medidos en los sedimentos de la estación CB2; y del factor 5, niveles elevados de concentraciones de $\mathrm{Cr}$ y $\mathrm{Hg}$ disueltus en el agua intersticial de sedimentos provenientes de diferentes estaciones, aunque es más patente en aquellos provenientes de la estación CB5.

Para la Bahía de San Francisco, se proponen que los contaminantes que son fuente de estrés en el ecosistema son: del factor $1, \mathrm{Hg}, \mathrm{PCB}_{\text {Tolal }}, \mathrm{Ag}, \mathrm{DDT}_{\text {Tolal }}, \mathrm{Cr}, \mathrm{Sn}, \mathrm{Ni}$, $\mathrm{Cu}, \mathrm{Zn}$ y $\mathrm{Pb}$, medidos en sedimentos de la zona de Islais Waterways; y del factor 4, el As, medido en sedimentos de las estaciones SP09 y OA02. 
CB1

CB2
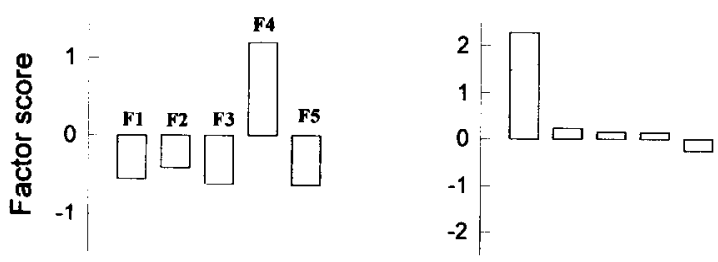

CB3

CB4
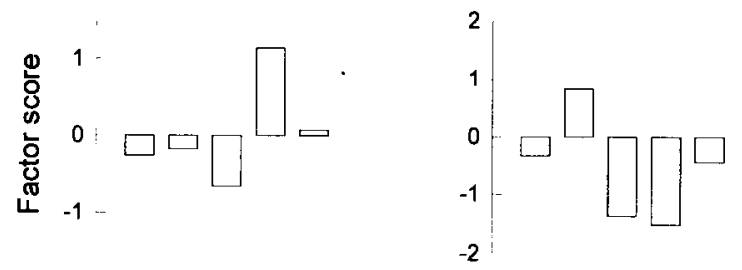

CB5

BR1
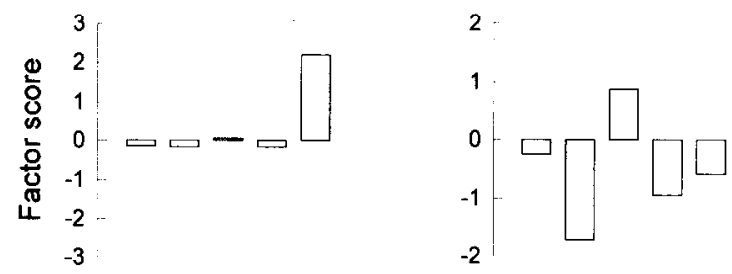

BR2

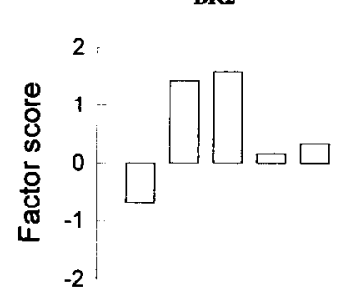

Figure 6. Factor scores estimated for each of the seven cases evaluated in the Gulf of Cádiz (five stations in the Bay of Cádiz: CB1, CB2, CB3, CB4 and CB5; and two stations at the salt-marsh of the Barbate River: BR1 and BR2) to the centroid of all cases for the original data. The factor scores quantify the prevalence of every factor for each station and are used to calculate the site-specific sediment quality values in sediment.

Figura 6. Contribuciones de los factores (factor scores) estimados para cada uno de los siete casos evaluados en el Golfo de Cádiz (cinco estaciones en la Bahía de Cádiz: CB1, CB2, CB3, CB4 y CB5; y dos estaciones en las marismas del río Barbate: BR1 y BR2) al centroide de todos los casos para los datos originales. La contribución de los factores cuantifica la influencia de cada factor para cada estación y se usa para calcular las guías de calidad de sedimento. 
SP02

SP05

SP09
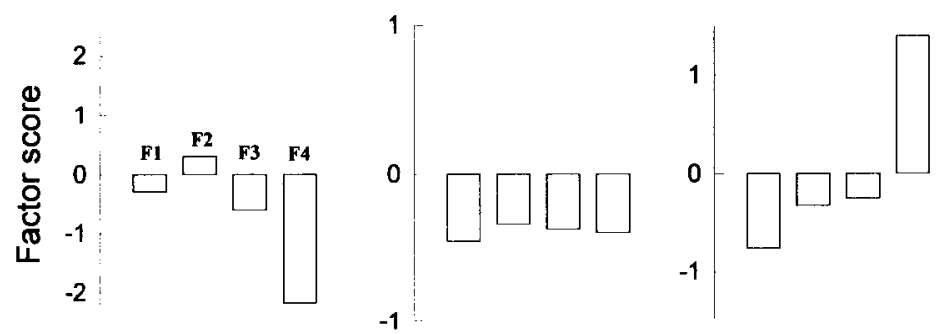

AO02

A005

A009

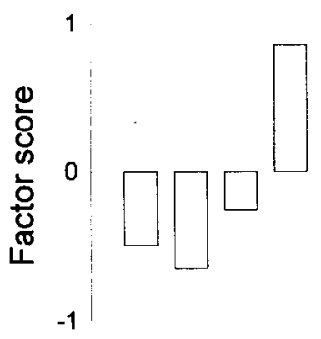

1

0

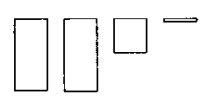

ISO2

ISO5

ISO5
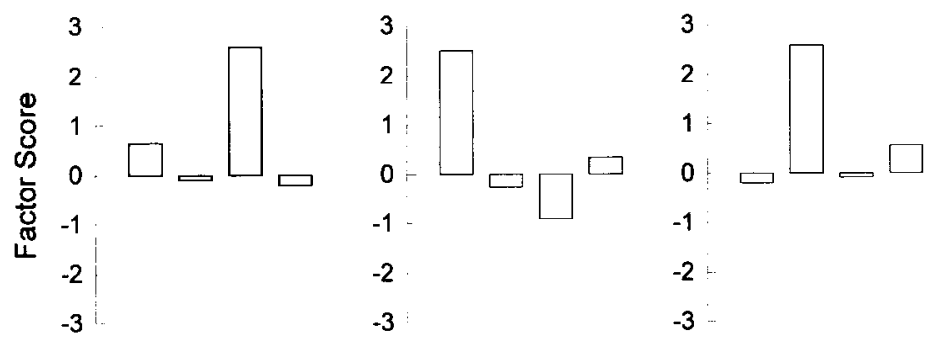

Figure 7. Factor scores estimated for each of the nine cases evaluated in San Francisco Bay to the centroid of all cases for the original data. The factor scores quantify the prevalence of every factor for each station and are used to calculate the site-specific sediment quality values in sediment.

Figura 7. Contribuciones de los factores (factor scores) estimados para cada uno de los nueve casos evaluados en la Bahía de San Francisco al centroide de todos los casos para los datos originales. La contribución de los factores cuantifica la influencia de cada factor para cada estación y se usa para calcular las guías de calidad de sedimento. 
three descriptions are shown in table 5. The rest of the chemicals measured in the different sediments selected in the Gulf of Cádiz appear in concentrations below the biological effects detected and were not associated with any adverse effect. In San Francisco Bay, the values (SQV) we propose for eleven different chemicals $(\mathrm{Cu}$, $\mathrm{Pb}, \mathrm{Ag}, \mathrm{Cr}, \mathrm{Hg}, \mathrm{Ni}, \mathrm{Sn}, \mathrm{Zn}, \mathrm{As}, \mathrm{PCB}_{\text {Total }}$ and $\mathrm{DDT}_{\text {Total }}$ ) according to the above three descriptions are shown in table 6 . The rest of the chemicals measured in the different sediments selected in San Francisco Bay appear in concentrations below the biological effect detected and were not associated with any adverse effect, except for the polyaromatic hydrocarbons that were measured as total concentration, so the authors do not consider it convenient to propose this kind of value.

The full applicability of the suggested sitespecific values (SQV) derived remains to be determined and they were evaluated based on comparisons to available benchmark sediment quality criteria and toxicity guideline values. In the absence of sediment criteria specific for the two littoral ecosystems studied, the guidelines obtained here were compared to the values derived from several approaches (table 7): sediment management guidelines proposed by the US Environmental Protection Agency, using site-specific sediment toxicity tests (US Army Corps of Engineers, 1977); Ontario Ministry of the Environment, using the screening level concentration (SLC) approach (Persaud et al, 1989); Washington State Marine Sediment Quality Standards, derived for Puget Sound using a combination of the apparent effects threshold (AET) and equilibrium patitioning (EqP) methodologies (WADOE, 1991); and National Oceanic and Atmospheric Administration (NOAA) from a compilation of the results of acute and chronic toxicity tests in several aquatic species (Long et al., 1995). The similarities reported between data obtained in this study and those proposed by the various agencies suggest that the sediment quality data from the Gulf of Cádiz and San Francisco Bay could converge on appropriate sediment quality guidelines for each area. However, it should be noted that we are suggesting a method for

\section{DISCUSIÓN}

Para confirmar estas descripciones de factores y para establecer los valores específicos de cada área de calidad de sedimento en los dos ecosistemas aquí estudiados (el Golfo de Cádiz y la Bahía de San Francisco), proponemos una representación del peso estimado de cada factor para cada caso (estaciones) al centroide de todos los casos en los datos originales (fig. 6 para cl Golfo de Cádiz y fig. 7 para la Bahía de San Francisco). Basándonos en los datos obtenidos de la aplicación del método SQT y utilizando la contribución (factor scores) de los factores en cada uno de los casos estudiados, se hacen las tres definiciones operativas siguientes. Cuando la contribución (F1 y F5) de los factores \#1 y \#5 en el Golfo de Cádiz y la contribución (F1, F3 y F4) de los factores \#1, \#3 y \#4 en la Bahía de San Francisco, los cuales muestran relaciones entre grupos de contaminantes y efectos biológicos adversos, son cero o menor de cero en las estaciones, la concentración máxima de contaminante tóxico en cualquiera de estas estaciones representa el máximo de la concentración de contaminantes no asociada con efectos adversos. Éstas son consideradas como concentraciones debajo de las cuales el efecto biológico es bajo o mínimo y se define aquí como "mínimo o ningún efecto biológico adverso". Por el contrario, para establecer la concentración mínima por encima de la cual aparece siempre el efecto biológico, se selecciona aquella concentración de contaminante mínima de las estaciones donde las contribuciones de los factores mencionados (F1 y F5 en el Golfo de Cádiz y F1, F3 y F4 en la Bahía de San Francisco) son siempre mayores que cero. Éstas son definidas aquí como "mayor efecto biológico adverso". También se define un intervalo intermedio de concentraciones de contaminantes representando un "área de incertidumbre" o punto de rotura entre concentraciones altas y bajas.

Los valores específicos, para cada sitio, de calidad de sedimento (SQV) propuestos para los cinco contaminantes distintos (LAS, $\mathrm{Pb}$, $\mathrm{Ag}, \mathrm{Cr}$ y $\mathrm{Hg}$ ) en el Golfo de Cádiz, de acuerdo con estas tres descripciones, se muestran en la 
Table 5. Sediment quality values for linear alkylbenzenesulphonate (LAS), lead, silver, chromium and mercury proposed for the Gulf of Cádiz area. All concentrations are expressed as $\mathrm{mg} \mathrm{kg}^{-1}$ of dry sediment.

Tabla 5. Guías de calidad de sedimento para alquilbencenosulfonato lineal (LAS), plomo, plata, cromo y mercurio propuestas para el área del Golfo de Cádiz. Todas las concentraciones están expresadas como $\mathrm{mg} \mathrm{kg}^{-1}$ de sedimento seco.

\begin{tabular}{lccc}
\hline Contaminants & \multicolumn{3}{c}{ Value descriptions } \\
\cline { 2 - 4 } & $\begin{array}{c}\text { No or minimal adverse } \\
\text { biological effects }\end{array}$ & $\begin{array}{c}\text { Major adverse } \\
\text { biological effects }\end{array}$ & Area of uncertainty \\
\hline $\mathrm{LAS}$ & $\leq 12.8$ & $\geq 62.0$ & $12.8<\mathrm{c}<62.0$ \\
$\mathrm{~Pb}$ & $\leq 66.8$ & $\geq 84.6$ & $66.8<\mathrm{c}<84.6$ \\
$\mathrm{Ag}$ & $\leq 1.2$ & $\geq 1.3$ & $1.2<\mathrm{c}<1.3$ \\
$\mathrm{Cr}$ & $\leq 101.2$ & $\geq 283.9$ & $101.2<\mathrm{c}<283.9$ \\
$\mathrm{Hg}$ & $\leq 0.46$ & $\geq 0.57$ & $0.46<\mathrm{c}<0.57$ \\
\hline
\end{tabular}

Table 6. Sediment quality values for copper, lead, silver, chromium, mercury, nickel, tin, zinc, arsenic, PCBs and DDTs proposed for the San Francisco Bay area. All concentrations are expressed as $\mathrm{mg} \mathrm{kg} \mathrm{kg}^{-1}$ of dry sediment, except for the DDT concentrations that are expressed as $\mu \mathrm{g} \mathrm{kg}^{-1}$ of dry sediment.

Tabla 6. Guías de calidad de sedimento para cobre, plomo, plata, cromo, mercurio, níquel, estaño, zinc, arsénico, PCBs y DDTs propuestas en el área de la Bahía de San Francisco. Todas las concentraciones están expresadas como $\mathrm{mg} \mathrm{kg}^{-1}$ de sedimento seco, excepto aquellas concentraciones de DDT que están expresadas como $\mu \mathrm{g} \mathrm{kg}^{-1}$ de sedimento seco.

\begin{tabular}{lccc}
\hline Contaminants & \multicolumn{3}{c}{ Value descriptions } \\
\cline { 2 - 4 } & $\begin{array}{c}\text { No or minimal adverse } \\
\text { biological effects }\end{array}$ & $\begin{array}{c}\text { Major adverse } \\
\text { biological effects }\end{array}$ & Area of uncertainty \\
\hline $\mathrm{Cu}$ & $\leq 68$ & $\geq 98$ & $68<\mathrm{c}<98$ \\
$\mathrm{~Pb}$ & $\leq 49$ & $\geq 115$ & $49<\mathrm{c}<115$ \\
$\mathrm{Ag}$ & $\leq 4.0$ & $\geq 8.1$ & $4.0<\mathrm{c}<8.1$ \\
$\mathrm{Cr}$ & $\leq 110$ & $\geq 134$ & $110<\mathrm{c}<134$ \\
$\mathrm{Hg}$ & $\leq 0.37$ & $\geq 0.57$ & $0.37<\mathrm{c}<0.57$ \\
$\mathrm{Ni}$ & $\leq 88$ & $\geq 15.0$ & $88<\mathrm{c}<94$ \\
$\mathrm{Sn}$ & $\leq 8.0$ & $\geq 225$ & $8.0<\mathrm{c}<15.0$ \\
$\mathrm{Zn}$ & $\leq 156$ & $\geq 64$ & $156<\mathrm{c}<225$ \\
$\mathrm{As}$ & $\leq 58$ & $\geq 0.180$ & $58<\mathrm{c}<64$ \\
$\mathrm{PCB}_{\text {Total }}$ & $\leq 0.057$ & $\geq 2.93$ & $0.057<\mathrm{c}<0.180$ \\
$\mathrm{DDT}_{\text {Total }}$ & $\leq 2.24$ & $2.24<\mathrm{c}<2.93$ \\
\hline
\end{tabular}


Table 7. Summary of benchmark sediment quality guidelines proposed for copper, lead, silver, chromium, mercury, nicke], zinc, arsenic, DDTs and PCBs by different North American agencies and government bodies. For the heavy metal tin and the surfactant LAS, guidelines were not available. All concentrations are expressed as $\mathrm{mg} \mathrm{kg}^{-1}$ of dry sediment, except those for the DDT concentrations that are expressed as $\mu \mathrm{g} \mathrm{kg}^{-1}$ of dry sediment.

Figura 7. Resumen de los valores guías de calidad de sedimento propuestos para cobre, plomo, plata, cromo, mercurio, níquel, zinc, arsénico, DDTs y PCBs por diferentes agencias de América del Norte. Las guías asociadas con el estaño y el tensioactivo LAS no estaban disponibles. Todas las concentraciones están expresadas como $\mathrm{mg} \mathrm{kg}^{-1}$ de sedimento seco, excepto aquellas referentes a las concentraciones de DDTs que están expresadas como $\mu \mathrm{g} \mathrm{kg}^{-1}$ de sedimento seco.

(A) Environmental Protection Agency, United States (US Army Corps of Engineers, 1977); (B) Ontario Ministry of the Environment (Persaud et al., 1989); (C) National Oceanic and Atmospheric Administration (Long et al., 1995); (D) Washington State (WADOE, 1991).

\begin{tabular}{|c|c|c|c|c|}
\hline \multirow[t]{2}{*}{ Chemical } & & \multicolumn{3}{|c|}{ Sediment quality guidelines } \\
\hline & & Not polluted & Moderately polluted & Highly polluted \\
\hline \multirow[t]{4}{*}{$\mathrm{Cu}$} & (A) & $<25$ & $25-50$ & $>50$ \\
\hline & (B) & $<15$ & $15-114$ & $>114$ \\
\hline & (C) & $<70$ & $70-390$ & $>390$ \\
\hline & (D) & $---*$ & $---*$ & $>390$ \\
\hline \multirow[t]{4}{*}{$\mathrm{Pb}$} & (A) & $<40$ & $40-60$ & $>60$ \\
\hline & (B) & $<23$ & 31 & $>250$ \\
\hline & (C) & $<35$ & $35-110$ & $>110$ \\
\hline & (D) & ---* & -.-* & $>450$ \\
\hline $\mathrm{Ag}$ & (C) & 1.0 & $1.0-2.2$ & $>2.2$ \\
\hline \multirow[t]{3}{*}{$\mathrm{Cr}$} & (A) & $<25$ & $25-75$ & $>75$ \\
\hline & (B) & $<22$ & $22-111$ & $>111$ \\
\hline & (C) & $<80.0$ & $80-145.0$ & $>145.0$ \\
\hline \multirow[t]{4}{*}{$\mathrm{Hg}$} & (A) & $<1.0$ & -.-* & $>1.0$ \\
\hline & (B) & $<0.12$ & $0.12-2.0$ & $>2.0$ \\
\hline & (C) & $<0.15$ & $0.15-1.3$ & $>1.3$ \\
\hline & (D) & $\ldots$ & $---*$ & $>0.41$ \\
\hline \multirow[t]{3}{*}{$\mathrm{Ni}$} & (A) & $<20$ & $20-50$ & $>50$ \\
\hline & (B) & $<31$ & $31-90$ & $>90$ \\
\hline & (C) & $<30$ & $30-50$ & $>50$ \\
\hline \multirow[t]{4}{*}{$\mathrm{Zn}$} & (A) & $<90$ & $90-200$ & $>200$ \\
\hline & (B) & $<65$ & $65-800$ & $>800$ \\
\hline & (C) & $<120$ & $120-270$ & $>270$ \\
\hline & (D) & $---*$ & $\ldots *$ & $>410$ \\
\hline \multirow[t]{4}{*}{ As } & (A) & $<3$ & $3-8$ & $>8$ \\
\hline & (B) & $<4$ & $4-33$ & $>33$ \\
\hline & (C) & $<33$ & $33-85$ & $>85$ \\
\hline & (D) & ---* & $---*$ & $>57$ \\
\hline $\mathrm{PCB}_{\text {Tolal }}$ & (B) & $<0.020$ & $0.020-0.041$ & $>0.041$ \\
\hline \multirow[t]{2}{*}{$\mathrm{DDT}_{\text {Total }}$} & (B) & $<5$ & $5-9$ & $>9$ \\
\hline & (C) & $<1$ & $1-7$ & $>7$ \\
\hline
\end{tabular}

* Guideline not available 
developing site-specific sediment quality values, not generic sediment quality values.

\section{ACKNOWLEDGEMENT}

The first author thanks the Comisión Interministerial de Ciencia y Tecnología Española (CICYT) for supporting the work described at the Gulf of Cádiz (project AMB94-0291).

\section{REFERENCES}

Chapman, P.M. (1991). Environmental quality criteria: What type should we be developing? Environ. Sci. Technol., 25: 1353-1359.

Chapman, P.M., Dexter, R.N. and Long, E.R. (1987). Synoptic measures of sediment contamination, toxicity and infaunal community structure (the Sediment Quality Triad) in San Francisco Bay. Mar. Ecol. Prog. Ser., 37: 75-96.

Comrey, A.L. (1973). A First Course in Factor Analysis. Academic Press, New York; 198 pp.

DelValls, T.A., Lubián, L.M., González del Valle, M. and Forja, J.M. (1996). Evaluating decline parameters of rotifer Brachionus plicatilis populations as an interstitial water toxicity test. Hydrobiologia, 341: 159-167.

DelValls, T.A., Lubián, L.M., Forja, J.M. and Gómez-Parra, A. (1997). Comparative ecotoxicity of interstitial waters using Microtox $\mathbb{B}$ and the rotifer Brachionus plicatilis. Environ. Toxicol. Chem., 16(11): 2323-2332.

DelValls, T.A., Forja, J.M. and Gómez-Parra, A. (1998a). An integrative assessment of sediment quality in littoral ecosystems from the Gulf of Cádiz. Environ. Toxicol. Chem., 17(6): 1073-1084.

DelValls, T.A., Forja, J.M. and Gómez-Parra, A. $(1998 \mathrm{~b})$. The use of multivariate analysis to link sediment contamination and toxicity data to establish sediment quality guidelines: an example in the Gulf of Cádiz (Spain). Ciencias Marinas, 24(2): 127-154.

DelValls, T.A., Forja, J.M,, González-Mazo, E., Blasco, J. and Gómez-Parra, A. (1998c). Determining contamination sources in marinc scdiments using multivariate analysis. TRAC-Trend Anal. Chem., 17(4): 181-192.

Frane, J., Jennrich, R. and Sampson, P. (1985). Factor analysis. In: W.J. Dixon (ed.), BMDP Statistical Software. Univ. California Press, Berkeley, pp. $480-500$. tabla 5. El resto de los contaminantes medidos en los sedimentos seleccionados en el Golfo de Cádiz aparecen en concentraciones por debajo de las cuales se midió el efecto biológico y no se les asoció con efecto adverso alguno. En la Bahía de San Francisco, se proponen valores (SQV) para once contaminantes diferentes $(\mathrm{Cu}$, $\mathrm{Pb}, \mathrm{Ag}, \mathrm{Cr}, \mathrm{Hg}, \mathrm{Ni}, \mathrm{Sn}, \mathrm{Zn}, \mathrm{As}, \mathrm{PCB}_{\text {Total }} \mathrm{y}$ $\left.\mathrm{DDT}_{\text {Total }}\right)$ de acuerdo con las tres descripciones mencionadas anteriormente y se muestran en la tabla 6. El resto de los contaminantes medidos en los sedimentos seleccionados en la Bahía de San Francisco aparecen en concentraciones por debajo de las cuales se midió el efecto biológico detectado y no se les asoció con efecto adverso alguno, excepto para los hidrocarburos poliaromáticos que fueron determinados como concentración total, por lo que los autores consideran que no es conveniente proponer esta clase de valores.

La aplicación completa de los valores sugeridos como de calidad de sedimento para las zonas específicas estudiadas (SQV) necesita ser determinada y fueron evaluados basándose en comparaciones con otros valores de calidad y guias de toxicidad derivados por diversos métodos (tabla 7). Para ello, se utilizaron guías de calidad de sedimento propuestas por la agencia norteamericana de conservación del medioambiente (USEPA), usando bioensayos específicos de sedimento (US Army Corps of Engineers, 1977); el ministerio del medioambiente de Ontario, utilizando el método del nivel de concentración de screening (SLC) (Persaud et al., 1989); los estándares de calidad de sedimento marino del estado de Washington, obtenidos para Puget Sound utilizando una combinación de los métodos de los efectos aparente de umbral (AET) y el método de la distribución en el equilibrio (EqP) (WADOE, 1991); y la oficina para la administración nacional del océano y la atmósfera norteamericana (NOAA), utilizando una recopilación de resultados obtenidos de ensayos crónicos y agudos de toxicidad sobre diferentes especies acuáticas (Long et al., 1995). La similitud apreciada entre los datos obtenidos en este estudio y entre los propuestos por las mencionadas agencias sugiere que los datos de calidad de sedimento para el Golfo de Cádiz podrían converger en apropiadas guías de 
Long, E.R., MacDonald, D.D., Smith, S.L. and Calder, F.D. (1995). Incidence of adverse biological effects within ranges of chemical concentrations in marine and estuarine sediments. Environ. Manag., 19(1): 81-97.

Persaud, D., Jaagumagi, R. and Hayton, A. (1989). Development of Provincial Sediment Quality Guidelines. Ontario Ministry of the Environment, Water Resources Branch, Aquatic Biology Section, Toronto, Ontario, $19 \mathrm{pp}$.

US Army Corps of Engineers (1977). Implementation Manual for Section 103 of Public Law 92-532: Marine Protection, Research and Sanctuaries Act of 1972, July 1977. US Army Corps of Engineers, Environmental Effects Laboratory, Waterways Experiment Section, Vicksburg, MS.

Washington State Department of Ecology (WADOE) (1991). Sediment Management Standards, Ch. 173-204 WAC. Sediment Management Unit, Olympia, Washington, April.

Zitko, V. (1994). Principal component analysis in the evaluation of environmental data. Mar. Pollut. Bull., 28: 718-722. calidad de sedimento, las cuales están apoyadas substancialmente por efectos biológicos disponibles y sinópticos, y podrían, de esta forma, ser ampliamente utilizadas. Sin embargo, y para no llevar a errores de interpretación, los autores quieren dejar claro que el objetivo del presente trabajo es solamente mostrar un método para desarrollar valores específicos de calidad de sedimento para áreas potencialmente sometidas a estudio, y no valores genéricos de calidad de sedimento.

\section{AGRADECIMIENTO}

El primer autor agradece a la Comisión Interministerial de Ciencia y Tecnología Española (CICYT) la financiación necesaria para desarrollar el trabajo descrito en el Golfo de Cádiz (proyecto AMB94-0291).

Traducido al español por el primer autor. 